\title{
Persistence of hepatic hepatitis B virus after serological clearance of HBsAg with autologous peripheral stem cell transplantation
}

\author{
George K K Lau, Pui Chee Wu, Raymond Liang, Siu Tsan Yuen, Wei Ling Lim
}

\begin{abstract}
Delayed clearance of hepatitis B surface antigen was previously reported in a 38 year old woman after high dose chemotherapy with autologous peripheral blood stem cell rescue. Sixteen months later, this patient remained hepatitis $B$ surface antigen negative, hepatitis $B$ surface antibody positive, and serum hepatitis B DNA negative by polymerase chain reaction. Serial liver biopsies (one at hepatitis B e antigen positive stage, one at hepatitis $B$ e antibody positive stage, and one at hepatitis $B$ surface antigen negative and hepatitis B surface antibody positive stage) showed a gradual resolution of the inflammatory activity with loss of hepatitis $B$ e antigen and then hepatitis $B$ surface antigen in the serum. However, the degree of fibrosis, though mild, remained the same. With the serological clearance of hepatitis $B$ surface antigen, a small amount of hepatitis B virus DNA was still detectable in the nuclei of liver cells.

( Clin Pathol 1997;50:706-708)
\end{abstract}

Keywords: hepatitis B virus; lymphoma; high dose chemotherapy; peripheral blood stem cell; virus persistence

Chronic hepatitis B infection (HBV) is a serious global health problem affecting approximately 300 million individuals. Of these, 20 to 40 per cent are likely to die of cirrhosis or hepatocellular carcinoma. Seventy five per cent of the $\mathrm{HBV}$ virus carriers are Chinese and most of them acquire the infection perinatally. Unfortunately, spontaneous loss of hepatitis B surface antigen (HBsAg) is a rare occurrence. ${ }^{1}$ The cause of viral persistence is largely unknown. $^{2}$ Previously, we reported our preliminary observation on the delayed clearance of HBsAg in a 38 year old woman 33 months after high dose chemotherapy with autologous peripheral blood stem cell rescue. ${ }^{3}$ Sixteen months after this serological clearance of HBsAg, she remains HBsAg negative, hepatitis B surface antibody (HBsAb) positive, and HBV DNA negative in serum by both dot hybridisation and polymerase chain reaction (PCR). Recently, it was found that traces of HBV are often detectable in the blood for many years after clinical recovery from acute hepatitis. ${ }^{4}$ In this study, we examined the serial changes in liver histology before and after recovery from chronic $\mathrm{HBV}$ infection in this patient, and the hepatic expression of $\mathrm{HBV}$ markers.

\section{Case report}

A 40 year old Chinese woman, known to be HBsAg positive since 1982, was diagnosed as having non-Hodgkin's lymphoma in December 1984. At that time, she was HBsAg positive, hepatitis $\mathrm{B}$ e antigen ( $\mathrm{HBeAg}$ ) positive, and serum HBV DNA positive (by dot hybridisation), with normal liver function tests (serum alanine aminotransferase $17 \mathrm{IU} / \mathrm{l})$. Seven courses of chemotherapy consisting of cyclophosphamide, doxorubicin, vincristine, and prednisone followed by local radiotherapy were given. This resulted in complete remission of the lymphoma.

During the treatment period (in December 1985), she had an episode of HBV reactivation (peak serum aminotransferase $1932 \mathrm{IU} / \mathrm{l}$ ) and liver biopsy at that time showed chronic active hepatitis (fig 1A). There was marked piecemeal plus bridging necrosis, marked intralobular degeneration and focal necrosis, marked portal inflammation, and fibrous portal expansion. The histological activity index (HAI) score was 15 (table 1). Immunohistochemistry showed $<1 \%$ of hepatocytes stained positive for both $\mathrm{HBsAg}$ and hepatitis B core antigen ( $\mathrm{HBcAg})$. HBV DNA was positive by in situ hybridisation in the cytoplasm of $75 \%$ of the hepatocytes. The patient had an uneventful recovery.

In February 1986, she had a lymphoma recurrence in the right submandibular region and was given another six courses of chemotherapy consisting of epirubicin, vincristine, cytarabine, prednisolone, and bleomycin, resulting in a second complete remission. During this second course of chemotherapy, there was no $\mathrm{HBV}$ reactivation and the patient remained $\mathrm{HBsAg}$ positive, $\mathrm{HBeAg}$ positive, and $\mathrm{HBV}$ DNA positive by dot hybridisation. In April 1986 , she seroconverted from $\mathrm{HBeAg}$ positive to $\mathrm{HBeAb}$ positive, with disappearance of serum HBV DNA by dot hybridisation, though positivity by PCR persisted.

In December 1990, the lymphoma recurred in her left cervical lymph nodes. She was given chemotherapy consisting of ifosphamide, methotrexate, and etoposide, resulting in a third complete remission. There was no HBV reactivation during this third course of chemotherapy and she remained HBsAg positive, $\mathrm{HBeAb}$ positive, and serum HBV DNA negative by dot hybridisation but positive by PCR. Liver biopsy in March 1991 showed 


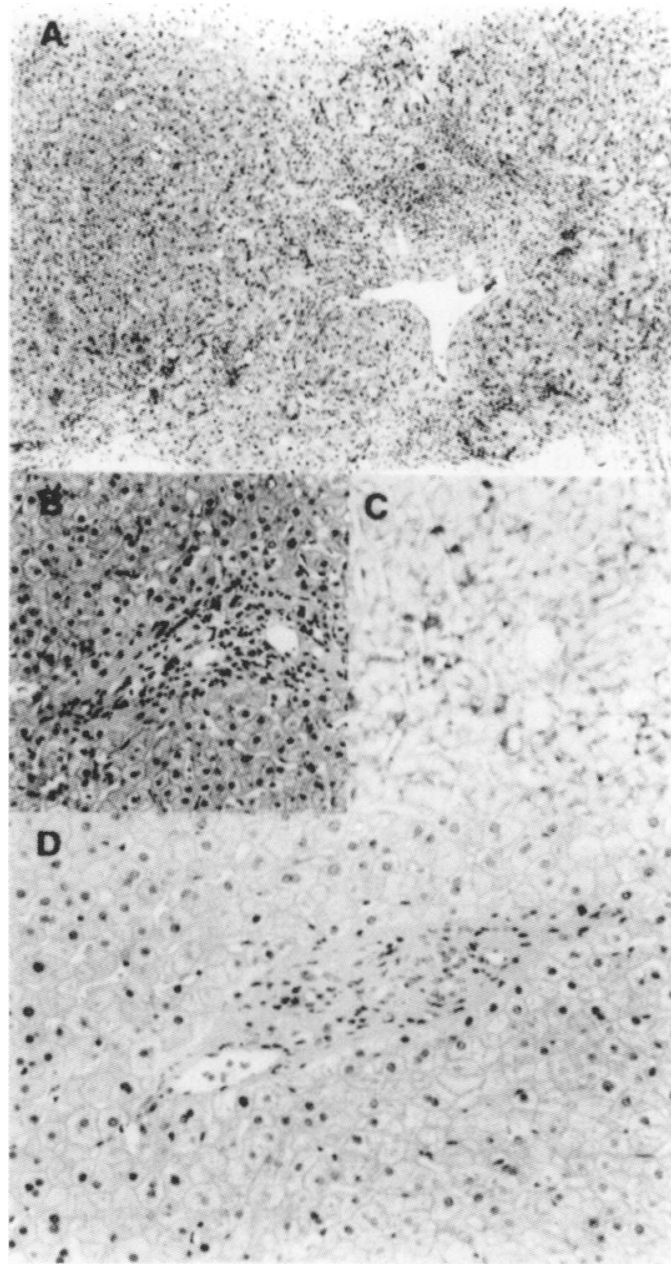

Figure 1 (A) Liver section showing marked portal inflammation with profound piecemeal and bridging necrosis (trichrome, $\times 70$ ). (B) Liver section showing mild portal inflammation and fibrous portal expansion, and mild piecemeal and focal necrosis (haematoxylin and eosin, $\times 110)$. (C) Immunohistochemical staining showing $30 \%$ of hepatocytes positive for hepatitis $B$ surface antigen $(\times 110)$. (D) Liver section showing only mild portal inflammation and fibrous portal expansion with no piecemeal or focal necrosis (haematoxylin and eosin, $\times 175$ ).

chronic persistent hepatitis. There was mild piecemeal necrosis, mild intralobular degeneration, mild portal inflammation, and fibrous portal expansion (fig 1B). Immunohistochemistry showed $30 \%$ staining for $\mathrm{HBsAg}$ and $0 \%$ for $\mathrm{HBcAg}$ (fig 1C). HBV DNA was positive by in situ hybridisation in the cytoplasm of $50 \%$ of the cells and $25 \%$ of hepatic nuclei. High dose

Table 1 Histological changes of serial liver biopsies

\begin{tabular}{|c|c|c|c|}
\hline & \multicolumn{3}{|c|}{ Date of liver biopsy } \\
\hline & $\begin{array}{l}2247 \text { days } \\
\text { before } B M T\end{array}$ & $\begin{array}{l}339 \text { days } \\
\text { before BMT }\end{array}$ & $\begin{array}{l}1484 \text { days } \\
\text { after } B M T\end{array}$ \\
\hline $\begin{array}{l}\text { Histological variables } \\
\text { Periportal }+/- \text { bridging necrosis }(0-10) \\
\text { Interlobular degeneration and focal necrosis }(0-4) \\
\text { Portal inflammation }(0-4) \\
\text { Fibrosis }(0-4) \\
\text { Total histological activity index score }\end{array}$ & $\begin{array}{r}6 \\
4 \\
4 \\
1 \\
15\end{array}$ & $\begin{array}{l}1 \\
1 \\
1 \\
1 \\
4\end{array}$ & $\begin{array}{l}0 \\
1 \\
1 \\
1 \\
3\end{array}$ \\
\hline $\begin{array}{l}\text { Hepatic expression of } H B V \\
\text { Immunohistochemistry } \\
\text { HbsAg+/HBeAg+ }(\%) \\
\text { In situ hybridisation } \\
\text { HBV DNA+ (\%) } \\
\text { Cytoplasm/nucleus }\end{array}$ & $<1 /<1$ & $50 / 25$ & $0 /<5$ \\
\hline$H B V D N A$ by $P C R$ & + & + & + \\
\hline
\end{tabular}

BMT, bone marrow transplant; HBV, hepatitis B virus; $\mathrm{HbsAg}$, hepatitis B surface antigen HbeAG, hepatitis $B$ e antigen; PCR, polymerase chain reaction. chemotherapy consisting of cyclophosphamide, carmustine, and etoposide with autologous peripheral stem cell rescue was given in February 1992. The peripheral blood stem cells were collected after granulocyte colony stimulating factor (G-CSF) mobilisation. The post-transplantation course was uneventful apart from grade 1 regimen related liver toxicity from day 20 to day 25 (peak bilirubin 33 $\mu \mathrm{mol} / \mathrm{l})$. Her liver function tests remained in the normal range thereafter. On day 379 , she was $\mathrm{HBsAg}$ positive, $\mathrm{HBeAg}$ negative, $\mathrm{HBeAb}$ positive, and HBV DNA negative by dot hybridisation but positive by PCR. In November 1994 (33 months after the high dose therapy), the patient seroconverted to become $\mathrm{HBsAg}$ negative, $\mathrm{HBsAb}$ positive, and serum HBV DNA negative by both dot hybridisation and PCR.

A third liver biopsy was performed on 19 March 1996. The histology showed only mild fatty changes with no piecemeal necrosis, very mild intralobular degeneration, very mild portal inflammation, and fibrous portal expansion (fig 1D). There was no $\mathrm{HBsAg}$ and $\mathrm{HBcAg}$ staining. However, liver cell nuclei were still positive ( $<5 \%$ of cells) by in situ hybridisation, and the liver was positive for HBV DNA by PCR.

\section{Methods used}

HEPATITIS SEROLOGY ASSAYS, SERUM AND TISSUE HBV DNA

Hepatitis B serological markers-HBsAg (Auszyme, monoclonal), HBsAb, HBeAg, $\mathrm{HBeAb}$; hepatitis C virus antibody (EIA II), hepatitis D virus antibody, and human immunodeficiency antibody-were all tested using commercially available enzyme immunoassays (Abbott Laboratories, Chicago, Illinois, USA). Clearance of HBsAg was confirmed by retesting using the polyclonal assay (Murex, Dartford, England). Serum HBV DNA was detected using dot hybridisation. ${ }^{5}$ HBV DNA was extracted from paraffin embedded liver tissue as described by Shindo et al. ${ }^{6}$ Nested PCR assay for the detection of serum extracted and tissue extracted HBV DNA was performed using primer sets from the surface antigen and the core antigen coding regions. ${ }^{5}$

\section{HISTOLOGICAL ASSESSMENT,}

IMMUNOHISTOCHEMISTRY, AND IN SITU HYBRIDISATION

The liver biopsies were assessed under code by a pathologist (PCW) who had no prior knowledge of the patient's clinical data or of the chronological order of the biopsy specimens. Chronic hepatitis was graded and staged using the histological activity index (HAI). ${ }^{7}$ The amount of HBV antigen in the liver biopsy samples was determined by standard immunohistochemistry (HBsAg, monoclonal antibody, Biogenex, San Ranom, California, USA; HBcAg, polyclonal, Dako, Carpentia, California, USA) on paraffin sections. The PAP kit (Amersham, Chicago, Illinois, USA) was employed, with peroxidase as the marker and diaminobenzidine as the substrate. Hepatic 
HBV DNA was detected by in situ hybridisation as described previously. ${ }^{8}$

\section{Discussion}

The patient we report here has been followed up at our clinic for more than 11 years (seven years before bone marrow transplantation and more than four years afterwards). This is the first documented report on the serological clearance of $\mathrm{HBsAg}$ following high dose chemotherapy and peripheral blood stem cell rescue. The patient has a definite history of chronic hepatitis $\mathrm{B}$, as evidenced by previous serology and histology. The mechanism for her loss of HBV viral markers (HBsAg and HBV DNA) is unknown. Loss of $\mathrm{HBsAg}$ is probably related to the high dose chemotherapy and autologous peripheral blood stem cell infusion, as the chance of spontaneous loss of $\mathrm{HBsAg}$ is extremely low, especially in Chinese $(0.1 \%$ to $0.8 \%)$.

No matter what mechanism was involved, this report suggests that the cause of HBV persistence is not clonal deletion but clonal suppression, as only autologous cells were involved. ${ }^{3}$ Hepatitis B e seroconversion occurred more than 300 days before the autologous bone marrow transplant. This was accompanied by lowering of HBV DNA in serum, which could not be detected by dot hybridisation but only by PCR. Histologically, even at this stage there was already marked reduction in necroinflammatory activity. This lowered HBV DNA level might have helped the subsequent clearance of $\mathrm{HBsAg}$ after autologous bone marrow transplantation. This is in analogy to the use of interferon in treating HBV, where a low HBV DNA level favours response. Similarly, it was our recent observation that a high pre-bone marrow transplant HBV DNA viral load might have prevented one of our allogeneic bone marrow transplant patients from clearing $\mathrm{HBsAg}$ after reception of $\mathrm{HBsAb}$ positive marrow. ${ }^{5}$

The loss of HBsAg occurred 33 months after the autologous bone marrow transplantation. This kind of delayed clearance has also been reported in patients treated with interferon. With seroconversion from $\mathrm{HBeAg}$ to $\mathrm{HBeAb}$ and then from $\mathrm{HBs} A g$ to $\mathrm{HBsAb}$, there was marked resolution of inflammatory components (marked piecemeal necrosis and bridging necrosis observed in the initial liver biopsy). However, the fibrous portal expansion, though mild, remained the same throughout the course. The histological picture probably represented an inactive burned out form of chronic active hepatitis. ${ }^{9}$
Though the patient is HBsAg negative and HBsAb positive, HBV DNA is still detectable in the liver tissue by in situ hybridisation and PCR. This low level of HBV, which persisted in the liver, probably represents active virus rather than integrated, non-replicative forms of genome. First, recrudescence of hepatitis B has been reported in $\mathrm{HBsAg}$ negative patients who have been treated with cancer chemotherapy, immunosuppressive regimens, or liver transplantation. ${ }^{10}$ Second, there have been several reports of transmission of hepatitis B by blood donations from $\mathrm{HBsAg}$ negative patients. ${ }^{11}$ Third, it has been shown that resolution of HBV infection with the development of $\mathrm{HBsAb}$ does not necessarily mean complete eradication of the virus. Recently, it was found that HBV specific cytotoxic T lymphocytes can be present as acute stage precursors long after recovery, displaying an activated phenotype (HLA-DR, CD 69), and can coexist with trace amounts of HBV DNA. These data suggest that the hepatitis $B$ virus is controlled by the cellular and humoral immune response rather than being completely eradicated after resolution of acute and chronic hepatitis B infection. ${ }^{4}$

1 Lok ASF. Natural history and control of perinatally acquired hepatitis B virus infection. Dig Dis 1992;10:46-52.

2 Vincenzo B, Balsano F. Immunologic and molecular basis of viral persistence. The hepatitis B virus model. $\mathcal{f}$ Hepatol 1992;14:391-400

3 Lau GKK, Liang R, Chiu EKW, Lee CK, Lam SK. Loss of HBsAg in chronic hepatitis $B$ carrier following high dose chemotherapy and autologous peripheral blood stem cell rescue for lymphoma [letter]. Am F Hematol 1995;50:31718.

4 Rehermann B, Ferrari C, Pasquinelli C, Chisari FV. The hepatitis $B$ virus persists for decades after patients' recovery from acute viral hepatitis despite active maintenance of a cytotoxic T-lymphocyte response. Nature Med 1996;2: cytotoxic

5 Lau GKK, Lok ASF, Liang R, Lai CL, Chiu EKW, Lau YL, et al. Clearance of chronic hepatitis B infection after bone marrow transplantation: role of adoptive immunity transfer. Hepatology 1997;25:1497-501

6 Shindo M, Okuno T, Arai K, Matsumoto M, Takeda M, Kashima K, et al. Detection of hepatitis B virus DNA in paraffin-embedded liver tissue in chronic hepatitis $B$ or non-A,non-B hepatitis using the polymerase chain reaction. Hepatology 1991;13:167-71.

7 Knodell RG, Ishak KG, Black WC, Chen T, Crag R, Kaplowitz N, et al. Formulation and application of a numerical scoring system for assessing histological activity in asymptomatic chronic active hepatitis. Hepatology 1981; in asymp.
$1: 431-5$.

8 Wu PC, Fang WS, Lai CL, Lau SK, Lo CK, Lai A, et al. Hepatic expression of hepatitis B virus genome in chronic hepatitis B virus infection. Am f Clin Pathol 1996;105:8795.

9 Fong TL, Di Bisceglie AM, Gerber MA, Waggoner JG, Hoofnagle JH. Persistence of hepatitis B virus DNA in the liver after loss of HBsAg in chronic hepatitis B. Hepatology 1993;18:1313-18.

10 Lok ASF, Liang RHS, Chiu EKW, Wong KL, Chan TK, Todd D. Reactivation of hepatitis B virus replication in patients receiving cytotoxic therapy. Gastroenterology 1991; patients receivi

11 Hoofnagle JH, Seeff LB, Bales ZB, Zimmerman HJ. Type B hepatitis after transfusion with blood containing antibody to hepatitis B core antigen. N Engl F Med 1978;298:137983. 